\title{
Mixture theory modeling for characterizing solute transport in breast tumor tissues
}

Sreyashi Chakraborty ${ }^{1}$, Alican Ozkan ${ }^{2}$, Marissa Nichole Rylander ${ }^{2,3,4}$, Wendy A. Woodward ${ }^{5}$ and Pavlos Vlachos ${ }^{1 *}$ (D)

\begin{abstract}
Background: Tumor numerical models have been used to quantify solute transport with a single capillary embedded in an infinite tumor expanse, but measurements from different mammalian tumors suggest that a tissue containing a single capillary with an infinite intercapillary distance assumption is not physiological. The present study aims to investigate the limits of the intercapillary distance within which nanoparticle transport resembles solute extravasation in a breast tumor model as a function of the solute size, the intercapillary separation, and the flow direction in microvessels.

Methods: Solute transport is modeled in a breast tumor for different vascular configurations using mixture theory. A comparison of a single capillary configuration (SBC) with two parallel cylindrical blood vessels $(2 \mathrm{BC})$ and a lymph vessel parallel to a blood vessel (BC_LC) embedded in the tissue cylinder is performed for five solute molecular weights between $0.1 \mathrm{kDa}$ and $70 \mathrm{kDa}$. The effects of counter flow (CN) versus co-current flow (CO) on the solute accumulation were also investigated and the scaling of solute accumulation-decay time and concentration was explored.

Results: We found that the presence of a second capillary reduces the extravascular concentration compared to a single capillary and this reduction is enhanced by the presence of a lymph vessel. Varying the intercapillary distance with respect to vessel diameter shows a deviation of 10-30\% concentration for 2 BC and 45-60\% concentration for BC_LC configuration compared to the reference SBC configuration. Finally, we introduce a non-dimensional time scale that captures the concentration as a function of the transport and geometric parameters. We find that the peak solute concentration in the tissue space occurs at a non-dimensional time, $T_{\text {peak }}^{*}=0.027 \pm 0.018$, irrespective of the solute size, tissue architecture, and microvessel flow direction.
\end{abstract}

Conclusions: This work suggests that the knowledge of such a unique non-dimensional time would allow estimation of the time window at which solute concentration in tissue peaks. Hence this can aid in the design of future therapeutic efficacy studies as an example for triggering drug release or laser excitation in the case of photothermal therapies.

Keywords: Solute transport, Breast tumor, Mixture theory modeling

\section{Background}

The total cost of cancer care in the United States is projected to increase by $39 \%$ from 2010 to 2020 [1]. Primary areas of cancer research involve improving the efficacy of chemotherapeutic agents at the tumor sites and minimizing their toxic side effects in the non-target sites [2-4]. Conventional chemotherapeutic agents [5] are non-specifically distributed in the body which limits the effectiveness of the drug dose and increases toxicity in normal cells. Drug carriers with

\footnotetext{
* Correspondence: pvlachos@purdue.edu

${ }^{1}$ Department of Mechanical Engineering, Purdue University, West Lafayette, IN 47907, USA

Full list of author information is available at the end of the article
}

hydrodynamic diameter 3-200 $\mathrm{nm}$ accumulate preferentially in tumors owing to the enhanced permeability and retention (EPR) effect [6] exploiting the wider pores in tumor vessels and the impaired lymphatic drainage in diseased tissues. The transport mechanism of these nanoparticles in tumors is a function of the hemodynamics, nanoparticle transport parameters (solute permeability, solute diffusivity, reflection coefficient) as well as the extravascular matrix properties (porosity, hydraulic conductivity). Before the binding/uptake by the cancer cell these particles overcome three major transport barriers: transport through microvasculature, translocation across the

(c) The Author(s). 2019 Open Access This article is distributed under the terms of the Creative Commons Attribution 4.0 International License (http://creativecommons.org/licenses/by/4.0/), which permits unrestricted use, distribution, and 
endothelial wall, and diffusion within the extracellular tissue matrix. Using a numerical model to investigate the nanoparticle transport mechanics could enable determination of the exact time interval between nanoparticle introduction and drug release to achieve desired therapeutic efficacy based on patient specific tumor measurements.

The majority of the existing multiscale models use the Darcy's law, Starling's law, and Poiseuille's law to analyze extravascular, trans-capillary, and intravascular transport respectively [7-12]. Poiseuille's law cannot account for variations in capillary diameter and the inhomogeneous nature of blood. Deviations from Starling's law are expected when osmotic terms would include other endogenous solutes in addition to proteins. Darcy's law does not include the dependence of interstitial flow on local fluid chemical potential. Schuff et al. [13, 14] used mixture theory equations in an axisymmetric tissue geometry containing a concentric blood vessel and showed the dependence of extravascular fluid transport on chemical gradients in addition to hydrostatic pressure which was previously suggested $[15,16]$ and observed [17] but not commonly accounted for in previous transport models. Recently developed tumor numerical models [11, 18, 19] focus on complex capillary distribution in the tissue, multi-stage drug delivery systems and dynamically changing tumor geometry but for the nutrient transport they rely on the advection-diffusion equation only instead of considering each type of particle (solute, fluid, cells etc) as a mixture component. In the present work, we focus on nanoparticle transport only, neglecting, drug pharmacokinetics, dynamic tumor geometry variation and complex capillary network to delineate a characteristic metric applicable to all kinds of solute and fluid transport in tumors. The mixture theory model is implemented in dual-tissue geometries to predict nanoparticle distribution in cancerous breast tissues over a wide range of particle sizes $(0.5-15 \mathrm{~nm})$ and molecular weights $(0.1-70 \mathrm{kDa})$.

We hypothesize that nanoparticle distribution in breast tumors is a function of solute size, intercapillary separation, and flow direction and there exists a characteristic nondimensional time, $T_{\text {peak }}^{*}$, for which solute concentration in the tissue space is maximum. We test this hypothesis by investigating the transport mechanisms of five solute types $(0.1,3,10,40$ and $70 \mathrm{kDa})$ in tumor systems containing a single vessel $(\mathrm{SBC})$ and compare with tumors possessing dual-vessel (blood capillaries only (2 BC), blood capillary and a lymph capillary (BC_LC)) tissue systems with varying intercapillary separation. The mixture theory equations are used for the first time and their predictive capability validated with measurements of dextran transport in an in vitro tumor platform containing multiple blood vessels.

\section{Results}

Numerical simulations with baseline values of breast tumor transport (Table 1) show a strong influence of vascular configurations on the solute accumulationdecay temporal history in the tissue space. A schematic of the vascularized breast tumor configuration along with the transport pathways is shown in Fig. 1. The blood vessel in Fig. 1 allows both intravasation and extravasation depicted by blue and red arrows respectively. The lymph vessel allows intravasation (blue arrow) only and drains the lymphatic fluid out of the tissue. All the equations used in the simulations are explained in the Appendix 1.

\section{Test 1: effect of solute size in three configurations for fixed intercapillary separation}

The effect of solute size in the double blood capillary (2 $\mathrm{BC}$ ) and the blood capillary -lymph vessel (BC_LC) configurations compared to the single capillary (SBC) is shown in Fig. 2. The tissue volume surrounding each capillary is equal.

The concentration-time history essentially shows an initial accumulation period until the solute reaches its maximum concentration in the tissue space, then it is followed by a concentration decay.

It is observed in the accumulation phase of the SBC configuration (Fig. 2a inset) the $0.1 \mathrm{kDa}, 3 \mathrm{kDa}$ and 10 $\mathrm{kDa}$ solutes attain peak concentration with 41.3, 40.3 and $30.7 \%$ of their maximum intravascular concentrations at 2.4, 4.2, and $7.2 \mathrm{~min}$ respectively whereas heavier solutes like $40 \mathrm{kDa}$ and $70 \mathrm{kDa}$ attain 26.9 and $30.5 \%$ of their maximum intravascular concentrations at 13.2 and 21 min respectively.

The time taken for $0.1 \mathrm{kDa}, 3 \mathrm{kDa}$ and $10 \mathrm{kDa}$ solutes to reduce to $10 \%$ of their maximum intravascular concentrations are $25.8,28.2$ and $37.2 \mathrm{~min}$ respectively whereas the same for the $40 \mathrm{kDa}$ and $70 \mathrm{kDa}$ solutes are 1.57 and $3.25 \mathrm{~h}$ respectively. The peak tissue concentration for $0.1 \mathrm{kDa}, 3 \mathrm{kDa}, 10 \mathrm{kDa}, 40 \mathrm{kDa}$ and $70 \mathrm{kDa}$ solutes decreases by $25,28,31,28$ and $25 \%$ respectively in the $2 \mathrm{BC}$ configuration (Fig. $2 \mathrm{~b}$ inset) and by 55,52 , 50,53 and $40 \%$ respectively in the BC_LC configuration (Fig. 2c inset) with respect to the SBC configuration. In comparison to the SBC tissue peak concentration, the peak occurs at later times (Fig. 2b) in $2 \mathrm{BC}$ configurations ( $3 \mathrm{kDa}$ : $6.6 \mathrm{~min}$ vs $4.2 \mathrm{~min}$; $10 \mathrm{kDa}$ : $9.6 \mathrm{~min}$ vs 7.2 min; $40 \mathrm{kDa}: 21 \mathrm{~min}$ vs $13.2 \mathrm{~min}$ ) and at earlier times (Fig. 2c) in BC_LC configurations ( $3 \mathrm{kDa} 3 \mathrm{~min}$ vs 4.2 min; $10 \mathrm{kDa}: 4.2 \mathrm{~min}$ vs $7.2 \mathrm{~min}$; $40 \mathrm{kDa}: 9.6 \mathrm{~min}$ vs 13.2 min). For the smallest solute $0.1 \mathrm{kDa}$, the concentration attains peak value later compared to its SBC counterpart (2.4 mins) in both the $2 \mathrm{BC}(4.2$ mins $)$ and BC_LC (3 mins) tissue spaces. On the contrary the largest $70 \mathrm{kDa}$ 
Table 1 Input parameters for mixture theory model. Values are for different types of cancer tissues adopted from the literature. References are listed in the last column of the table

\begin{tabular}{|c|c|c|c|c|c|c|}
\hline \multicolumn{7}{|l|}{ Solute Dependent Parameters } \\
\hline Solute Molecular Weight (kDa), Mw & 0.1 & 3.0 & 10.0 & 40.0 & 70.0 & \\
\hline Hydrodynamic Diameter (nm) & 0.69 & 1.6 & 5.46 & 13.2 & 14.4 & [20-22] \\
\hline Reflection coefficient, $\boldsymbol{\sigma}$ & 0.00025 & 0.00025 & 0.02500 & 0.08600 & 0.14000 & {$[13,14,23,24]$} \\
\hline Solute Permeability coefficient, $P_{d}\left(\times 10^{-8} \mathrm{~m} / \mathrm{s}\right)$ & 800 & 174 & 70 & 33 & 30 & {$[13,14,25-27]$} \\
\hline Diffusion Coefficient $\left(\times 10^{-11} \mathrm{~m}^{2} / \mathrm{s}\right), D_{f}$ & 89.6 & 17.0 & 9.6 & 7.8 & 3.6 & [28-31] \\
\hline Retardation factor, $R_{F}$ & 1.10 & 1.10 & 1.07 & 0.94 & 0.84 & [29-33] \\
\hline Initial solute concentration $\left(\mathrm{mol} / \mathrm{m}^{3}\right)$, Co & 6.11 & 0.20 & 0.08 & 0.02 & 0.01 & [28] \\
\hline \multicolumn{7}{|l|}{ Flow Parameters } \\
\hline Pressure drop along blood vessel (Pa), dP & & & 2394 & & [34-37] & \\
\hline Hydrostatic pressure in arteriole (Pa), Par & & & 4394 & & [34-37] & \\
\hline Boundary tissue pressure (Pa), Po & & & 2700 & & [38-41] & \\
\hline Osmotic Pressure gradient (Pa) & & & 2500 & & {$[13,14,20,34]$} & \\
\hline Hydraulic conductivity $\left(\times 10^{-15}\right)\left(\mathrm{m}^{2} / \mathrm{Pa}-\mathrm{s}\right)$ & & & 400 & & {$[13,14,39,42]$} & \\
\hline Hydraulic permeability $\left(\times 10^{-10}\right)(\mathrm{m} / \mathrm{Pa}-\mathrm{s})$ & & & 10 & & {$[13,14,39]$} & \\
\hline Tissue porosity, $\varnothing$ & & & 0.4 & & {$[39,43-45]$} & \\
\hline \multicolumn{7}{|l|}{ Geometrical Parameters } \\
\hline Length of microvessels (mm), I & & & 1 & & {$[46,47]$} & \\
\hline Diameter of microvessels $(\mu \mathrm{m}), d$ & & & 10 & & {$[46,48,49]$} & \\
\hline Diameter of tissue $(\mu \mathrm{m}), \mathrm{D}$ & & & 200 & & {$[46,48,50-52]$} & \\
\hline
\end{tabular}
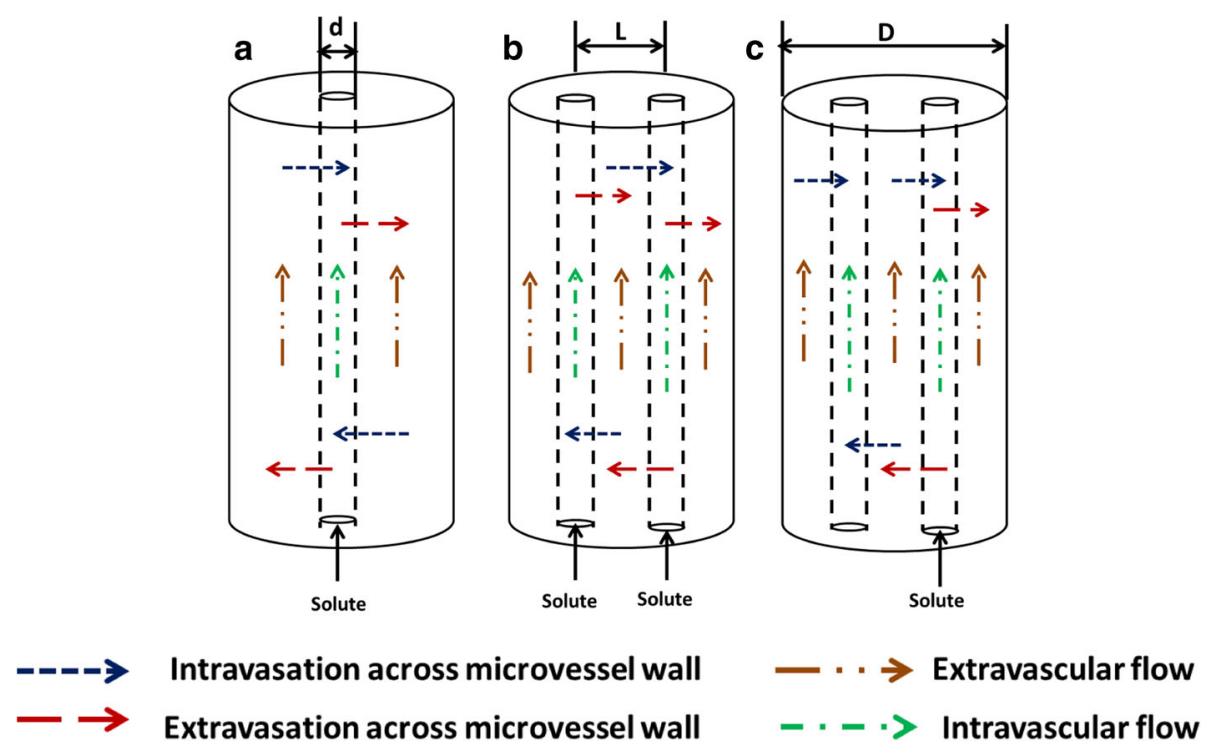

Fig. 1 Three schematic tissue configurations with transport pathways that have been numerically modelled. a single capillary embedded in tissue cylinder b) parallel flow blood capillaries in tissue cylinder c) lymph vessel parallel to blood vessel enclosed in tissue cylinder. $d$ is the capillary diameter, $\mathrm{L}$ is the intercapillary separation and $\mathbf{d}$ is tissue diameter. The arrows show the main transport mechanisms of a solute in the tissue. The extravascular space contains interstitial fluid flowing through a fibrous matrix. The blood vessel contains an inner core of red blood cells (RBC) surrounded by an outer plasma layer. The lymph vessel contains the interstitial fluid in it. No extravasation occurs in lymph vessels 


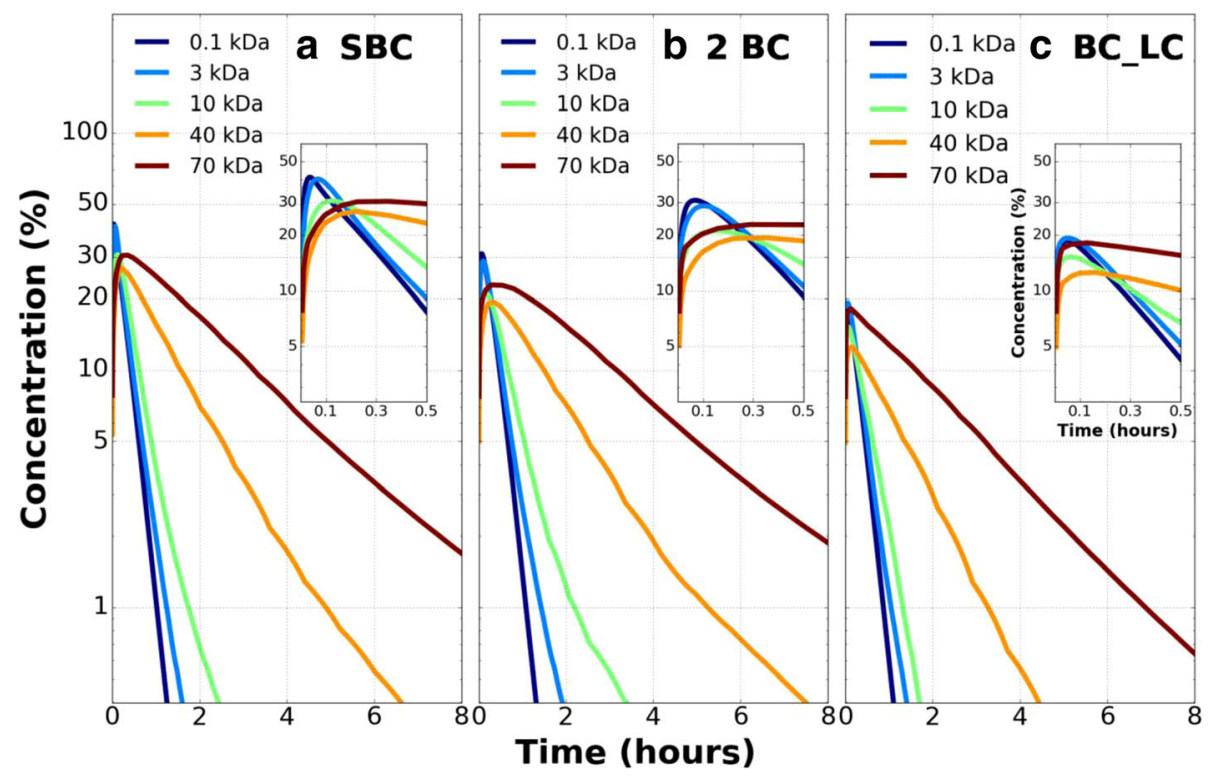

Fig. 2 Extravascular concentration-time history of five solutes in a) the SBC configuration b) The 2 BC configuration and c) the BC_LC configuration. Extravascular solute concentration is normalized by the maximum intravascular concentration in the blood capillary volume. Solute concentration in the tissue space decreases with time and varies with solute size. The inset in each subplot is a magnified view to show the concentration variation at earlier times for all three vessel configurations

solute attains peak concentration earlier in both $2 \mathrm{BC}$ (17 mins) and BC_LC (7.8 mins) extravascular spaces compared to its SBC counterpart (21 mins). The $70 \mathrm{kDa}$ solute, however, exhibits a faster onset of concentration decay both in the $2 \mathrm{BC}$ and $\mathrm{BC} \_\mathrm{LC}$ configuration (SBC: $21 \mathrm{~min} ; 2$ BC:17.4 min; BC_LC:7.8 min) while a delayed concentration decay is seen for the $0.1 \mathrm{kDa}$ solute (SBC: $2.4 \mathrm{~min}$; 2 BC:4.2 min; BC_LC:3 min).

\section{Test 2: effect of flow direction in microvessels}

The microvessel flows considered in test 1 are in the same axial direction and are called co-current (CO) flows. They are compared with oppositely directed axial flows in the microvessels which are called counter current $(\mathrm{CN})$ flows. Figure 3 compares the $\mathrm{CN}$ flow with the $\mathrm{CO}$ flow for $2 \mathrm{BC}$ configuration and BC_LC configuration respectively. In both configurations there is no difference between the two flow types during the solute accumulation phase in the tissue.

As the tissue concentration decays, the extravascular solute concentration is less in $\mathrm{CN}$ flow at later times compared to $\mathrm{CO}$ flow. The percentage reduction in concentration is more pronounced for larger $(10 \mathrm{kDa}$ : $0.5 \%$; $40 \mathrm{kDa}: 1.7 \%$; $70 \mathrm{kDa}$ : $2.5 \%)$ solutes in $2 \mathrm{BC}$ configuration (Fig. 3a, b). A similar observation is made for heavier (10 kDa: 0.12\%; $40 \mathrm{kDa}: 0.4 \%$; $70 \mathrm{kDa}: 0.5 \%)$ solutes but the difference is less in BC_LC configuration (Fig. 3c, d) compared to the $2 \mathrm{BC}$ configuration. The faster drainage in presence of additional capillaries delays the solute accumulation. Thus, it takes a longer time for the solute to reach its peak concentration in a tissue location and compared to SBC configuration the magnitude of the peak accumulation is lower.

\section{Test 3: effect of intercapillary separation on transport of $3 \mathrm{kDa}$ and $10 \mathrm{kDa}$ solutes}

The intercapillary separation $(\mathrm{L})$ was varied with respect to the vessel diameter (d) in the next set of tests for the $2 \mathrm{BC}$ and BC_LC configurations. We calculated the surface averaged extravascular concentration at a radial distance $0.2 \mathrm{~L}$ from the blood vessel wall in SBC configuration $\left(\mathrm{C}_{\mathrm{SBC}}\right)$ as well as in the $2 \mathrm{BC}$ configuration $\left(\mathrm{C}_{2 \mathrm{BC}}\right)$ where $\mathrm{L}$ is the intercapillary separation (Fig. 4a).

The percentage deviation between these two terms is plotted in Fig. 4b across different values of nondimensional intercapillary separation $(\mathrm{L} / \mathrm{d}=1,5,10,25$, 125) for $3 \mathrm{kDa}$ and $10 \mathrm{kDa}$ solute.

The dotted lines represent $\mathrm{L} / \mathrm{d}$ values of 5 (yellow) and 21.5 (purple) which are the lower and upper limits of normalized intercapillary separation in breast tumors. L/d values above 21.5 are typically found in normal (non-diseased) tissues.

Double blood capillary $(2 \mathrm{BC})$ embedded in tissue cylinder The $2 \mathrm{BC}$ configuration shows minimum deviation $(3 \mathrm{kDa}$ : $1.5 \% ; 10 \mathrm{kDa}: 2.5 \%$ ) from the $\mathrm{SBC}$ configuration for $\mathrm{L} / \mathrm{d}=$ 

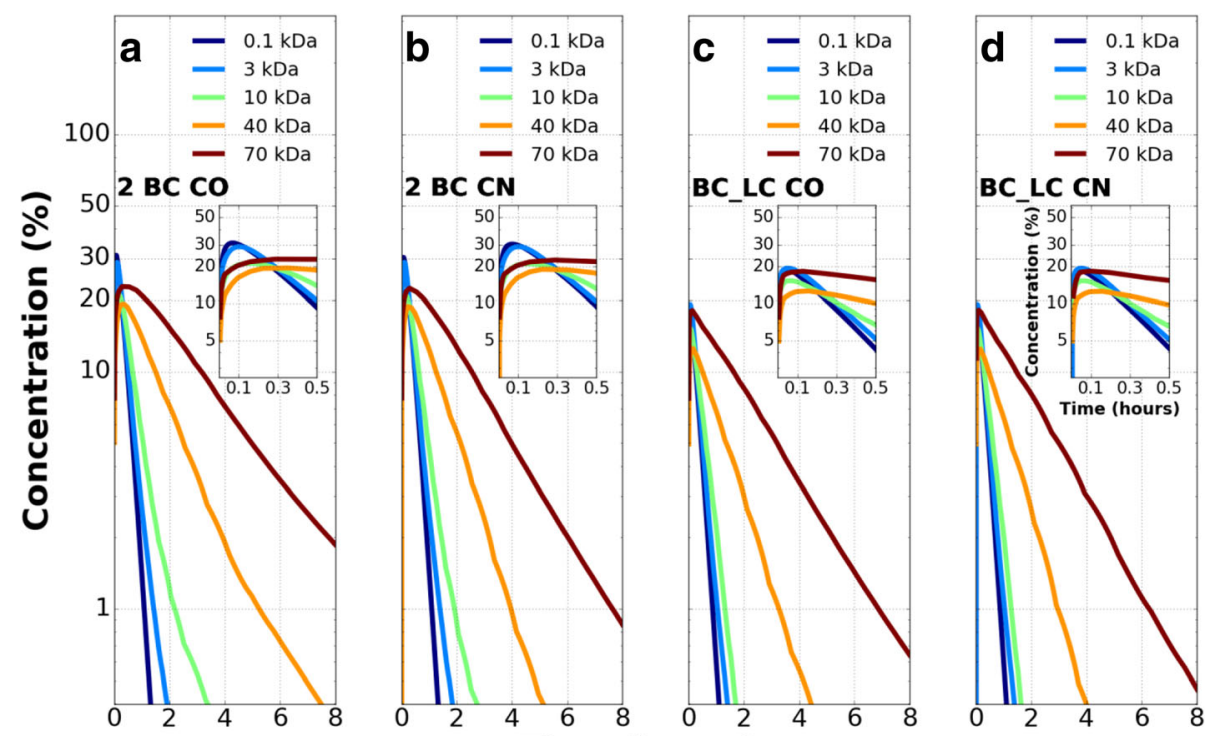

Time (hours)

Fig. 3 Extravascular concentration-time history of five solutes for a) Co-current (CO) flow in microvessels in 2 BC configuration b) Counterflow $(\mathrm{CN})$ in microvessels in $2 \mathrm{BC}$ configuration c) Co-current (CO) flow in microvessels in BC_LC configuration and d) Counterflow (CN) in microvessels in BC_LC configuration. Extravascular solute concentration is normalized by the maximum intravascular concentration in the blood capillary volume. Counterflow $(\mathrm{CN})$ reduces the solute concentration in tissue space more than co-current flow $(\mathrm{CO})$ in parallel capillary configuration

1 (Fig. 4b). This is because the spacing between two blood capillary walls is so small that they effectively function as a single capillary with twice the original capillary diameter. So, the solute accumulation almost the resembles that in a SBC configuration. The solute concentration deviation is substantial (9-33\%) for $L / d=5-25$ which is the range of interest as reported in Table 2. The isolated capillary assumption will not hold true for extravascular solute accumulation in this regime. The deviation $(3 \mathrm{kDa}: 4.7 \% ; 10$ $\mathrm{kDa}: 8.5 \%$ ) reduces for $\mathrm{L} / \mathrm{d}=125$ because the large spacing between capillary walls minimizes the cumulative effect of the two blood vessels on the peak tissue concentration.
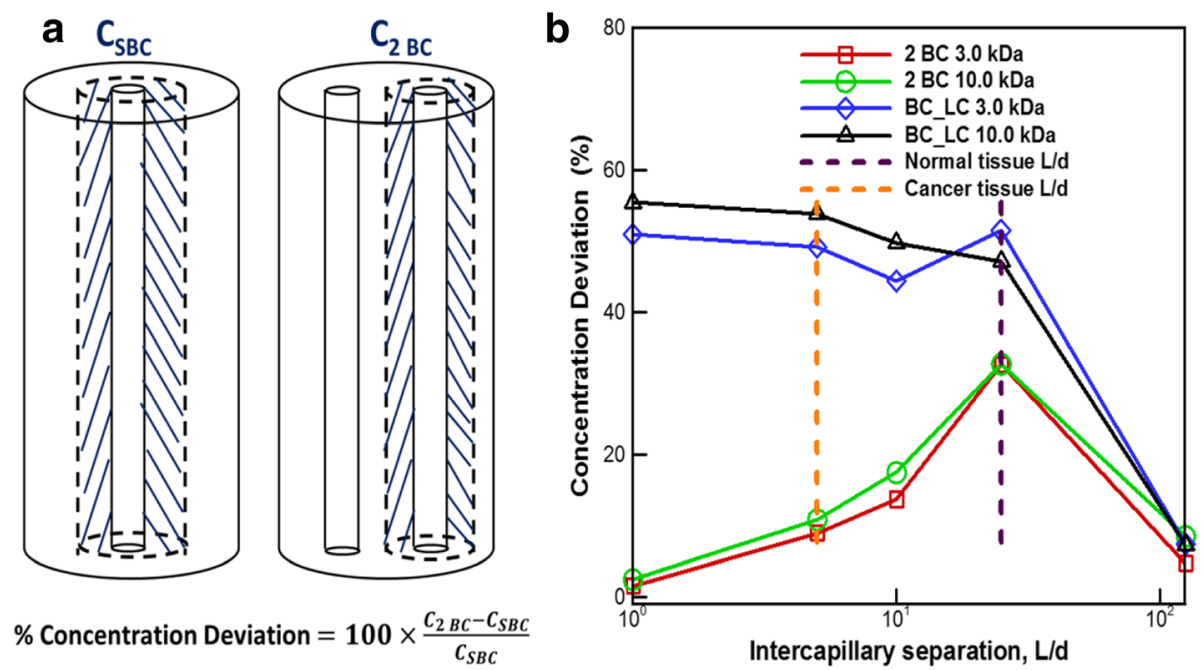

Fig. 4 a Schematic showing the setup and the calculation of \% concentration deviation. b Non-dimensional intercapillary separation (L/d) between 5 and 25 shows significant deviation of solute concentration in 2 BC and BC_LC configurations compared to SBC configuration for 3 kDa and $10 \mathrm{kDa}$ solute sizes. The dotted lines represent L/d values of 5 (yellow) and 21.5 (purple) which are the lower and upper limits of normalized intercapillary separation in breast tumors. L/d values above 21.5 are typically found in normal (non-diseased) tissues 
Table 2 Intercapillary distance from invivo tissues with capillary diameer, $d=10 \mu m$

\begin{tabular}{|c|c|c|c|}
\hline Tissue Type & $\begin{array}{l}\text { Intercapillary } \\
\text { Separation }(\mathrm{L}, \boldsymbol{\mu} \boldsymbol{m})\end{array}$ & $\mathrm{L} / \mathrm{d}$ & References \\
\hline Rat mammary tumors & 50 & 5 & {$[46]$} \\
\hline Rabbit neoplastic tissue & 101 & 10.1 & {$[50]$} \\
\hline Mammary carcinoma & $80-135$ & $8-13.5$ & $\begin{array}{l}{[51][53][52]} \\
{[48]}\end{array}$ \\
\hline Normal breast tissue & 215 & 21.5 & [53] \\
\hline Human large intestine & 107 & 10.7 & [54] \\
\hline $\begin{array}{l}\text { Human colorectal tumor } \\
\text { periphery }\end{array}$ & 54 & 5.4 & {$[55]$} \\
\hline $\begin{array}{l}\text { Human colorectal tumor } \\
\text { center }\end{array}$ & 177 & 17.7 & {$[55]$} \\
\hline
\end{tabular}

\section{Blood capillary and lymph capillary (BC_LC) embedded in tissue cylinder}

The BC_LC configuration (Fig. 4b) shows minimum deviation (3 kDa: 7.4\%; $10 \mathrm{kDa}$ : 7.3\%) from the $\mathrm{SBC}$ configuration for $\mathrm{L} / \mathrm{d}=125$ due to the same reason as the $2 \mathrm{BC}$ configuration. But with decreasing $\mathrm{L} / \mathrm{d}$ the sink action of the lymph vessel become increasingly dominant resulting in $44-55 \%$ deviation of the maximum solute concentration in tissue volume from that in the corresponding $\mathrm{SBC}$ configuration in the $\mathrm{L} / \mathrm{d}$ regime of 1 to 25 .

\section{Non-dimensional time vs peak non-dimensional concentration analysis}

The results discussed in the previous cases have shown that the variation of solute size, microvessel arrangement, number of microvessels and intercapillary separation all contribute differently to the solute accumulation time vs solute decay time in the tissue space.

Hence the non-dimensional extravascular solute concentration $\left(\mathrm{C}^{*}\right)$ and non-dimensional time $\left(\mathrm{T}^{*}\right)$ were calculated for all test cases to account for variations of these four parameters. The non-dimensional profiles for fixed $\mathrm{L} / \mathrm{d}=1$, 5, 10, 25, 125 were plotted in Fig. 5a. All concentration peaks lie within $\mathrm{T}^{*}=0.1$ shown by the dotted black line. So, in Fig. 5b the scaled concentration time-histories from $\mathrm{T}^{*}=0$ to $\mathrm{T}^{*}=0.1$ were analyzed. The peaks were extracted and plotted in Fig. 5c. The solid line red curves that correspond to the largest intercapillary distance $(\mathrm{L} / \mathrm{d}=125)$ have $T_{\text {peak }}^{*}$ values which are one order of magnitude less than the average $T_{\text {peak }}^{*}$. This is because for a large $\mathrm{L}$, the second vessel does not contribute to the solute accumulation in the measurement location which is at a distance $0.2 \mathrm{~L}$ from the first blood vessel. The concentration gradients across each capillary wall dynamically change the extravascular flux across the wall and for a large $\mathrm{L}$ the solute may get trapped within a certain distance of the capillary. The non-dimensional equations do not account for these and hence the deviation of $T_{\text {peak }}^{*}$ for $\mathrm{L} / \mathrm{d}=125$. It was concluded that the average non-dimensional time at which the peak concentration occurs in all configurations for all solutes is $T_{\text {peak }}^{*}=0.027 \pm 0.018$ (Fig. 5c).

\section{Discussion}

We present a numerical model for breast tumor that can predict passive transport of nanoparticles across a multilayer barrier when the tissue architecture and nanoparticle properties are specified. The solute size (molecular weight and hydrodynamic diameter) influences its extravascular concentration dynamically across time. Smallest solutes are cleared faster from the tissue but they are also susceptible to getting trapped in the recirculation zone set up by countercurrent blood flow in adjacent vessels [56, 57]. High clearance rates measured for solutes $<10 \mathrm{kDa}$ during in vivo measurements in tumors validate this observation. The therapeutic outcome of breast cancer drugs (Doxorubicin: $0.54 \mathrm{kDa}$; Cisplatin: $0.3 \mathrm{kDa}$ ) having similar molecular weight as the smallest solute investigated here can now be predicted for patient-specific tumor biopsies.

Heavier nanoparticles $(50-200 \mathrm{kDa})$ are preferred vehicles for the tumor location specific targeting and drug delivery [57, 58]. According to the results, heavier solutes with hydrodynamic diameter $(5-14 \mathrm{~nm})$ take longer to attain maximum accumulation at a specific tissue location and are also removed slowly [59,60]. Presence of adjacent blood vessels with counter-current flow accelerate the clearance process owing to drainage from both ends of the tissue. Presence of a lymph vessel reduces the magnitude of their peak concentration considerably owing to high permeability cross the lymph capillary wall. In various in vitro/in vivo studies the lymph wall is shown to allow unidirectional flow only [61-64] that facilitates better drainage. Easy removal of all sizes of drugs through the lymphatic system contributes to role of lymphatics in worse response [65].

Blood vessels have been mostly modelled as nonporous structures permeable to solutes embedded in the flow $[66,67]$. To our knowledge, this is the first numerical model that account for endothelial porosity directly measured from dextran transport in an in vitro breast tumor model. Additionally, this work shows inclusion of multiple vessels in a tumor numerical model is necessary to accurately measure transport phenomena. The SBC assumption works only for tissues where capillaries are so close $(L / d=1)$ that they act as a single vessel, e.g. when nearby lymph vessels collapse [61, 62, 64, 65] during metastasis of some cancers or if they are so far 

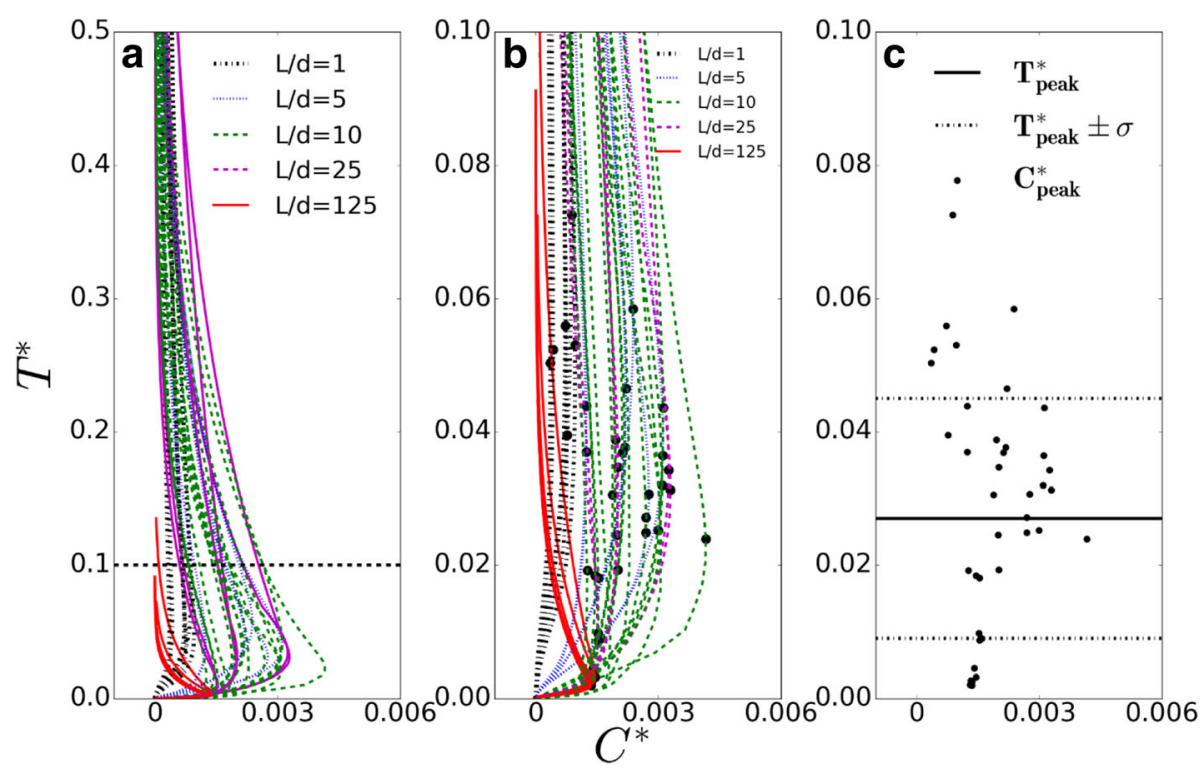

Fig. 5 a Non-dimensional concentration time history (T* vs $\left.C^{*}\right)$ for all solute sizes in all tissue configurations with varying intercapillary separation b) A magnified view of the non-dimensional concentration time history to identify time occurrences of peak concentrations $\left.\left(C^{*}\right) \mathbf{c}\right)$ The peak concentration $\left(\mathrm{C}^{*}\right)$ values are plotted separately to find an average non-dimensional time of occurrence as $0.027\left(\boldsymbol{T}_{\text {peak }}^{*}\right) \pm 0.018\left(\boldsymbol{\sigma}_{\text {std }}\right)$

apart $(\mathrm{L} / \mathrm{d}=125)$ that the solute flux from one does not reach the other.

The dextran transport investigated using a fabricated 3D microfluidic platform measured tissue porosity, endothelial porosity, nanoparticle permeability and nanoparticle diffusivity. Simulations driven by these parameters showed a close correspondence of numerical and experimental concentration-time histories. These parameters, when reported in literature, span over several orders of magnitude. The wide range can be attributed to the complex in vivo measurements whose intrusive nature would perturb the tissue microenvironment [17, 68]. Thus, the ability to measure these parameters in vitro can be used to design future non-invasive transport investigation studies.

Condensing all the effects of tissue architecture, solute and fluid transport properties, we suggest there exists a unique time $T_{\text {peak }}^{*}$ at which nanoparticle concentration in the tissue is maximum. Previous analytical solutions of a convective-dispersive solute transport equation with time-dependent inlet boundary condition [69, 70] have shown the dependence of time constant on the input timescale, convection timescale, decay timescale and the diffusion timescales but did not account for varying intercapillary separation. Later Chapman et al. and other researchers $[8,11,12,71]$ modeled transport in tumors characterized by intercapillary separation but did not account for the dynamic change of hydraulic permeability as a function of concentration gradients which in turn modulates the extravascular solute flux. The presented work, for the first time, analyzes the solute concentration in the tissue in the light of mixture theory equations for varying solute types, two parallel microvessels, differing flow directions in parallel vessels and tissue architecture and proposes a non-dimensional time at which solute concentration is maximum in the tissue.

Since this approach non-dimensionalizes the intercapillary separation (L) with the vessel diameter (d), $T_{\text {peak }}^{*}$ can be predicted for tissues ranging over several scales and also for different disease stages (cancer vs normal). This prediction would aid in efficient endothelial targeting, triggering drug release and laser excitation for photothermal therapies [72-74]. The $T_{\text {peak }}^{*}$ estimation can hugely impact the clinical landscape as it would customize treatment based on tumor specificity. Future studies with varying nanoparticle design, changing dosage, presence of magnetic targeting, receptor binding can all be implemented first to the mixture theory model whose predictions would increase the efficacy of the targeted drug delivery in patient specific tumors.

The major limitation associated with the study are as follows: The complex vascular network have been simplified. The tortuosity and diameter variation of the microvessels were neglected. The extracellular matrix was considered stationary and not allowed to deform. A zero flux boundary condition was prescribed at each 
microvessel outlet which deviates from the physiological condition where a constant solute flux is drained to other organs like the liver from the microvessel outlets.

\section{Conclusions}

The study described in this paper focuses on quantification of solute transport across parallel blood vessels and initial lymph vessels in the light of mixture theory. Transport of nanoparticles to the targeted tumor volume is defined by the transport through microchannels, diffusion across endothelium and transport within the porous matrix, all of which were accounted for in the presented work. The results show that the solute size strongly influences its own rate of removal and rate of accumulation in the tissue. The flow physics in the extravascular space facilitate tissue drainage of nanoparticles depending on the solute size, the intercapillary separation and the microvessel arrangement in the tissue.

A unique non-dimensional time $T_{\text {peak }}^{*}$ was reported for the first time for peak solute accumulation in absence of pharmacokinetics. This is the time at which peak concentration of a nanoparticle occurs at any tissue location. The knowledge of the nanoparticle introduction time, tissue mechanical properties and solute dependent properties will allow, in future, to design in vitro tissue models testing various nanoparticle designs and concomitantly, predict for patient specific tumors, the appropriate time of drug release that can substantially improve drug efficacy.

\section{Methods}

\section{Mixture theory model parameters}

The mixture theory model requires fifteen input parameters that account for the mechanical properties of the porous matrix, type of the injected solute, and vascular geometry. The governing equations and boundary conditions for the mixture theory model have been derived in [13]. A sensitivity analysis of the input parameters, calibration and subsequent validation of the model was carried out by Schuff et al. in [14]. The mixture theory equations model the transport $[13,14]$ of the fluid and solute in three distinct regions of a representative vascularized tumor geometry: a) in the intravascular space which consists of the plasma layer concentric with an inner core of red blood cells, b) across the capillary wall which is thin and semi-permeable and c) the extravascular space that comprises of the interstitial fluids and solutes flowing through a fibrous matrix. A finite element software package COMSOL 4.2 (COMSOL, Burlington, MA) was used to run the simulations. The simulation run time for each solute transport in a specific tissue configuration was 1.5 days.

\section{Experimental validation of mixture theory model}

The accuracy of the computational model was confirmed with experimental measurements performed in a 3D vascularized in vitro tumor microenvironment. Essential model parameters such as tissue porosity, vessel porosity, solute permeability, and solute diffusivity were measured using the in vitro platform and implemented in the model (Table 3). The concentration-time histories were obtained from the mixture theory equations using the minimum, maximum, and mean values of the tissue parameters measured from in vitro platform. The simulation results were also compared with experimental measurements from dextran transport in the same vascularized in vitro platform (Fig. 6). Details explaining the fabrication and measurement of porosity, solute permeability and solute diffusivity from the fabricated platform can be found in the Appendix 2. To our knowledge, this is the first in vitro model that measured different porosity values in the extravascular and intravascular spaces.

\section{Experimental and numerical comparison of concentration- time histories}

Numerical simulations for the model validation studies were separately processed with identical tissue properties and boundary conditions as obtained from the experiment. The intensity-time histories were spatially averaged at a radial location of $600 \mu \mathrm{m}$. These were normalized by the maximum intensity inside the vessel at that time instant. For each of $3 \mathrm{kDa}$ and $70 \mathrm{kDa}$ solutes, transport was studied in $N=3$ tissue samples with identical fabrication parameters. The normalized intensity profile of dextran particles from these experiments corresponds to the normalized concentration from the numerical simulations (Fig. 6). The error bars correspond to the experimental variability observed across 3 samples at each time instant. For $3 \mathrm{kDa}$, the

Table 3 Parameters from the fabricated tissue platform used in the equivalent simulation

\begin{tabular}{|c|c|c|c|}
\hline $\begin{array}{l}\text { Parameters from } \\
\text { fabricated tissue } \\
\text { platform }\end{array}$ & Mean & Min & Max \\
\hline Vessel diameter $(\boldsymbol{\mu} \mathrm{m})$ & 715 & - & - \\
\hline Tissue diameter ( $\boldsymbol{\mu}$ m) & 3000 & - & - \\
\hline Tissue Porosity & 0.53 & 0.49 & 0.59 \\
\hline Vascular Porosity & 0.4 & 0.37 & 0.43 \\
\hline $\begin{array}{l}\text { Solute Diffusivity } \\
\left(\mathrm{m}^{2} / \mathrm{s}\right)\end{array}$ & $\begin{array}{l}3 \text { kDa: } 25 e-11 \\
70 \text { kDa: } 4.3 e-11\end{array}$ & $\begin{array}{l}3 \text { kDa: } 20 \mathrm{e}-11 \\
70 \text { kDa: } 3.7 e-11\end{array}$ & $\begin{array}{l}3 \text { kDa: } 30 e-11 \\
70 \text { kDa: } 4.9 e-11\end{array}$ \\
\hline $\begin{array}{l}\text { Solute Permeability } \\
(\mathbf{m} / \mathrm{s})\end{array}$ & $\begin{array}{l}3 \text { kDa: } 32 e-8 \\
70 \text { kDa: } 9 e-8\end{array}$ & $\begin{array}{l}3 \text { kDa: } 24 e-8 \\
70 \text { kDa: } 7 e-8\end{array}$ & $\begin{array}{l}3 \text { kDa: } 43 e-8 \\
70 \text { kDa: } 11 e-8\end{array}$ \\
\hline $\begin{array}{l}\text { Hydraulic Permeability } \\
\left(\boldsymbol{m}^{\mathbf{2}}\right)\end{array}$ & $1 e-12$ & - & - \\
\hline
\end{tabular}




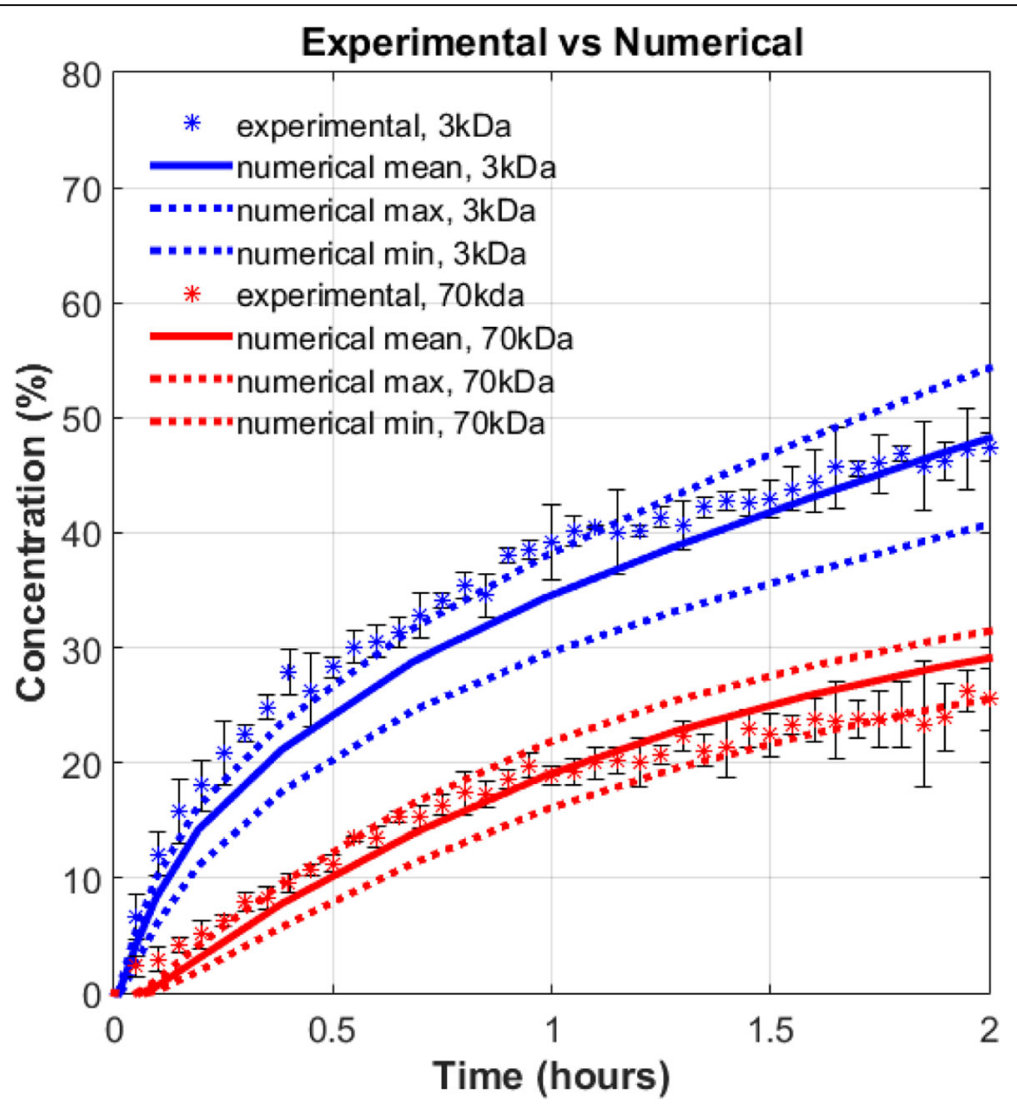

Fig. 6 Comparison of experimental and numerical normalized concentration-time histories for $3 \mathrm{kDa}$ and $70 \mathrm{kDa}$ solutes in a single capillary cancer tissue

smaller solute, the experimental data till $1 \mathrm{~h}$ matches with the simulation curve from maximum values of input parameters. The deviation of experimental results from mean simulated values decreases with increasing time from $1 \mathrm{~h}$ to $2 \mathrm{~h}$. The higher deviation of the $3 \mathrm{kDa}$ numerical curves from the experimental curve can be attributed to the higher susceptibility of the small solutes $(<10 \mathrm{~nm})$ to get trapped in local recirculation zones in a non-homogeneous tissue $[56,64]$. The experimental data for the $70 \mathrm{kDa}$ solute almost coincide with the mean simulation curve and is closely enveloped by the maximum and minimum simulation curves.

\section{Vascular tissue configurations and test matrix}

In the current study three geometrical configurations of the vessels in the tissue are considered: the single blood capillary (SBC) configuration, the double blood capillary (2 BC) configuration, the blood capillary and the lymph vessel (BC_LC) configuration. The simulations were split into 3 tests listed in Table 4. The flow direction is same $(\mathrm{CO})$ in parallel microvessels for tests 1 and 3. The intercapillary distance (L) in the dual-microchannel configurations is $100 \mu \mathrm{m}$ in tests 1 and $2[29,48,52]$.

\section{Test 1: effect of solute size on transport}

Five solutes $(0.1 \mathrm{kDa}, 3 \mathrm{kDa}, 10 \mathrm{kDa}, 40 \mathrm{kDa}, 70 \mathrm{kDa})$ are injected at the inlet of the blood capillaries in each configuration to delineate the effect of solute size on transport. The geometry, hydraulic parameters and

Table 4 Test matrix developed for conducting the study

\begin{tabular}{clll}
\hline Configuration & $\begin{array}{l}\text { Flow } \\
\text { Direction } \\
\text { Type }\end{array}$ & $\begin{array}{l}\text { Intercapillary } \\
\text { separation }(\mu \mathrm{m})\end{array}$ & $\begin{array}{l}\text { Solute Molecular } \\
\text { weight }(\mathrm{kDa})\end{array}$ \\
\hline $\begin{array}{l}\text { Test 1: Effect of solute size } \\
\text { SBC }\end{array}$ & N/A & N/A & $0.1,3.0,10.0,40.0,70.0$ \\
2 BC & CO & 100 & $0.1,3.0,10.0,40.0,70.0$ \\
BC_LC & CO & 100 & $0.1,3.0,10.0,40.0,70.0$
\end{tabular}

Test 2: Effect of flow direction in microvessels

$\begin{array}{llll}2 B C & C O & 100 & 0.1,3.0,10.0,40.0,70.0 \\ 2 B C & C N & 100 & 0.1,3.0,10.0,40.0,70.0 \\ \text { BC_LC } & C O & 100 & 0.1,3.0,10.0,40.0,70.0 \\ \text { BC_LC } & C N & 100 & 0.1,3.0,10.0,40.0,70.0\end{array}$

Test 3: Effect of intercapillary separation
$\mathrm{SBC}$
N/A
N/A
3.0, 10.0
$2 B C \quad C O \quad 10,50,100,250,1250$
$3.0,10.0$
BC_LC
CO
$10,50,100,250,1250$ 
transport properties of the solute molecules in a breast tumor are in Table 1. The transport properties of 0.1 $\mathrm{kDa}$ solute are estimated from the calibration model developed in [14].

\section{Test 2: effect of flow direction in capillaries on transport}

The second test investigates the influence of co-current flow and counter-current flow in both $2 \mathrm{BC}$ and BC_LC tissue configurations and compares the solute transport mechanisms with the SBC configuration.

\section{Test 3: effect of intercapillary separation on transport}

In the third test, the capillary separation $(\mathrm{L})$ is varied with respect to blood capillary diameter $(\mathrm{d}),(\mathrm{L} / \mathrm{d}=1,5$, $10,25,125)$, to test the solute accumulation in the tissue space as compared to the SBC configuration.

Due to long computational time for each solute, this test is run for two solutes, $3 \mathrm{kDa}$ (representative of a therapeutic drug) and $10 \mathrm{kDa}$ (representative of the size of drug carrying nanoparticle). The intercapillary separation, $\mathrm{L}$, is defined as the shortest distance measured between all non-adjacent capillary pairs in a loop [46]. The tissue diameter (D) is twice the separation value $(\mathrm{D}=2 \mathrm{~L})$ to maintain the same volume of tissue around each microvessel with respect to the SBC configuration. The surface averaged extravascular concentration is calculated at a radial distance $0.2 \mathrm{~L}$ from the blood vessel wall in $\mathrm{SBC}$ configuration $\left(\mathrm{C}_{\mathrm{SBC}}\right)$ as well as in the $2 \mathrm{BC}$ configuration $\left(\mathrm{C}_{2 \mathrm{BC}}\right)$. The percentage concentration deviation shown in Fig. $4 \mathrm{a}$ is compared across different values of intercapillary separation. The intercapillary distances for different tissue types in humans and small animals are recorded in Table 2. The blood capillary diameter, d, is $10 \mu \mathrm{m}$ in accordance with the values reported in literature across humans, mice and rats [46, 48, 49]. The L/d for tissue types shown in Table 2 lies between 5 and 21.5. So, the analysis was performed for $L / d=1,5$, 10, 25 and 125 for two solute molecular weights of $3.0 \mathrm{kDa}$ and $10 \mathrm{kDa}$. For all the tests, the average extravascular concentration in the tissue volume surrounding the blood capillary is measured for each configuration. They are normalized by the maximum intravascular concentration in the blood capillary volume and the concentration-time history for each test is analyzed in the Results section.

\section{Non-Dimensionalization of the convection-diffusion-decay process}

The final objective of this paper is to assimilate results of tests 1, 2 and 3 to provide a unique non-dimensional time at which tissue solute concentration is maximum. The solute concentration-time histories in specific radial locations of the tissue space are influenced by the drainage of the solutes in addition to the advection diffusion and decay processes as modelled by Eq. $1 . \mathrm{S}$ is the density of the micro vessels (unit is no of vessels $/ \mathrm{m}$ ) whose walls act as a sink in the tissue volume. The product of $\mathrm{S}$ and solute permeability $\left(P_{d}^{s}\right)$ is the decay constant k.

We assume exponential decay and define $\tau$ as the time when the inlet concentration drops to $36.7 \%(1 / \mathrm{e})$ of the maximum inlet concentration. The first form of Eq. 1 is non-dimensionalized to find the time scales of the other transport mechanisms involved. Defining the following scaled variables $C s *=\frac{c^{s}}{C o} ; t *=\frac{t}{\tau} ; x *=\frac{x}{L} ; U f *=\frac{u f}{U o}$, where $U_{o}$ is the average velocity of fluid in tissue. Substituting these in Eq. 1; we get the non-dimensional form as shown in Eq. 2.

$$
\begin{gathered}
\phi \frac{\partial c^{s}}{\partial t}+R_{F}^{s} u f . \nabla c^{s}+\nabla \cdot\left(-\phi D \text { tissue } \nabla c^{s}\right)=-k c^{s} \\
\phi \frac{\partial c^{s}}{\partial t}+R_{F}^{s} u f . \nabla c^{s}+\nabla \cdot\left(-\phi D \text { tissue } \nabla c^{s}\right)=-P_{d}^{s} S c^{s} \\
\frac{\phi}{\tau} \frac{\partial C s *}{\partial t *}+R_{F}^{s} \frac{U o}{L} U f * . \nabla C s * \\
+\frac{D t i s s u e}{2} L^{2} \nabla \cdot(-\phi \nabla C s *)=-k C s *
\end{gathered}
$$

The effect of $\tau$ on the solute accumulation in a tissue space is modified by the number of microvessels (n) present around it and the intercapillary separation $(\mathrm{L} / \mathrm{d})$ between them. The solute dependent timescales, obtained from Eq. 2 are the modified input time scale $\left(n \tau \frac{L}{d}\right)$, the diffusion timescale $\left(\frac{L^{2}}{D_{\text {tissue }}}\right)$ and the decay timescale $\left(\frac{1}{k}\right)$. These values for each solute in SBC configuration are shown in Table 5. Since different timescales are dominant at different phases and radial locations of transport for differing solute types, a sum of all the solute dependent time scales is used to non-dimensionalize the time of solute accumulation and decay in tissue as shown in Eq. 3.

Table 5 Solute dependent timescales that influence concentration in tissue across time

\begin{tabular}{llll}
\hline Solute $(\mathrm{kDa})$ & $\begin{array}{l}\text { Input timescale } \\
(\tau)(\mathrm{s})\end{array}$ & $\begin{array}{l}\text { Diffusion timescale } \\
\left(\frac{L^{2}}{\text { Dtisue }}\right)(\mathrm{s})\end{array}$ & $\begin{array}{l}\text { Decay timescale } \\
(1 / \mathrm{k})(\mathrm{s})\end{array}$ \\
\hline 0.1 & 284.5 & 25.4 & 125 \\
3 & 440.1 & 133.4 & 574.7 \\
10 & 604.8 & 241.7 & 1428.6 \\
40 & 1302 & 328.2 & 3030.3 \\
70 & 2319 & 778.9 & 3333.3 \\
\hline
\end{tabular}




$$
T *=\frac{t}{n \tau \frac{L}{d}+\frac{L^{2}}{\text { Dtissue }}+\frac{1}{k}}
$$

The extravascular concentration is rescaled to account for the variable solute molecular weight $(\mathrm{Mw})$, solute density $(\rho)$, tissue porosity $\varnothing$, inlet solute concentration (Co) and varying intercapillary separation (L/d) as defined by Eq. 4.

$$
C *=\frac{\rho}{\phi M w} \cdot \frac{L}{d} \cdot \frac{1}{C o}
$$

\section{Appendix 1}

\section{Mixture theory model equations}

The conservation of mass and linear momentum equations from which the mixture theory equations are derived are stated below. The equation derivation steps are described in $[13,14]$ by Schuff et al. A representative tissue configuration is shown in Fig 7.

\section{Balance of Mass}

Assuming zero rate of mass production of constituent $\alpha$ with density $\rho^{\alpha}$ and velocity $\boldsymbol{u}^{\alpha}$ in a mixture, the general expression for mass balance at each region is $\frac{\partial \rho^{\alpha}}{\partial t}+\nabla \cdot\left(\rho^{\alpha} u^{\alpha}\right)=0 \cdot \boldsymbol{u}^{\alpha}$ is related to the extravascular/ Darcy velocity of the same constituent as $\mathrm{U}^{\alpha}=\phi^{\alpha} \mathrm{u}^{\alpha}$ where $\phi^{\alpha}$ is the volume fraction of constituent $\alpha$. In each region the mixture was assumed to be saturated (i.e $\sum_{\alpha} \phi^{\alpha}=1$ ). For the extravascular space, assuming incompressible flow and a stationary solid matrix, the mass conservation equation reduced to $\nabla \cdot \mathrm{U}^{f}=\nabla \cdot\left(\phi^{f} \mathrm{u}^{f}\right)$ $=0$. In our simulations due to assumption of dilute solution, $\phi^{f}=1, \phi^{s}=\phi$.

\section{Balance of Linear Momentum}

Assuming absence of body forces per unit volume of any tumor space, the momentum equation for the constituent $\alpha$ is $\rho^{\alpha} \frac{d^{\alpha} u^{\alpha}}{d t}=\nabla \cdot\left(\mathrm{T}^{\alpha}\right)+\prod^{\alpha}$ where $\frac{d^{\alpha}(.)}{d t}=\frac{\partial(.)}{\partial t}+u i^{\alpha} \frac{\partial(.)}{\partial x i}$ is the material derivative, $\mathrm{T}^{\alpha}=-\phi^{\alpha} P I+\phi^{\alpha} \hat{\mathrm{T}}^{\alpha}$ is the Cauchy stress tensor, $\mathrm{P}=$ pore pressure and $\hat{\mathrm{T}}^{\alpha}$ is the stress tensor for a dense configuration of constituent $\alpha$. For fluids with viscosity $\mu^{f}, \hat{\mathrm{T}}^{f}=\mu^{f}\left(\nabla \mathrm{u}^{f}+\left(\nabla \mathrm{u}^{f}\right)^{T}\right)$. Assuming a dilute solution of solutes in the tumor, solute-solute interactions are negligible for constituent $\mathrm{s}$, $\hat{\mathrm{T}}^{s}=0 . \Pi^{\alpha}$ accounts for the interaction terms between

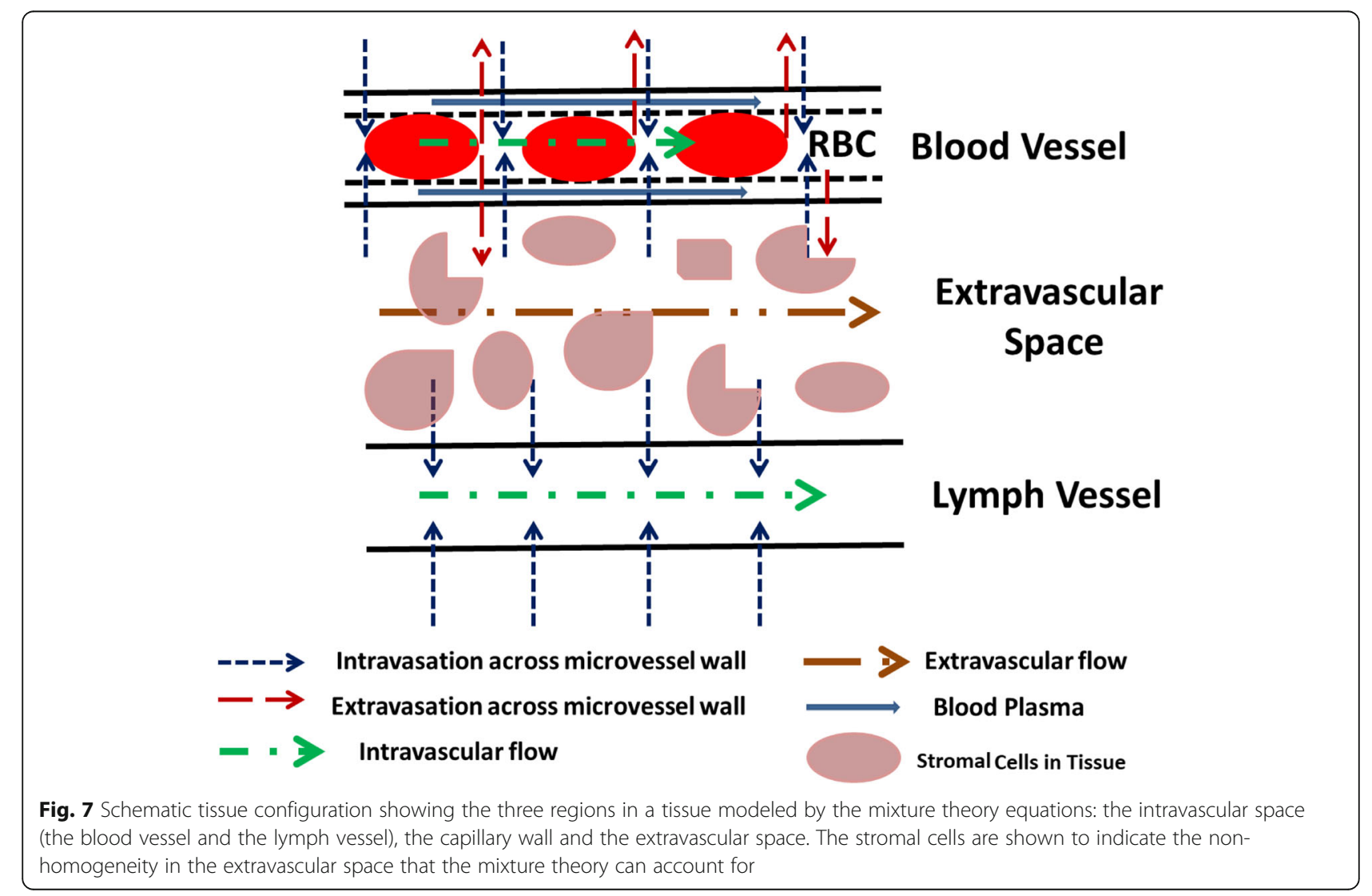


the different types of constituents and is subjected to the constraint $\sum_{\alpha} \prod^{\alpha}=0$. The final forms of equations in the intravascular space, capillary wall and extravascular space are given below.

\section{Fluid transport Equations}

Intravascular Space: The arterial pressure, Par, is specified at the inlet while the prescribed hydrostatic pressure difference, $\nabla P$ balances the viscous stresses to govern the fluid flow inside the capillaries according to Eq. 5.

$$
-\nabla P+\mu \nabla^{2} u f=0
$$

Capillary Wall: At the capillary wall, jump boundary conditions are applied as $\left[\left[\phi^{f}\left(\mathrm{u}^{f}\right)\right]\right] \cdot \mathrm{n}=0$. The [[a]] denotes the difference of the quantity "a" across the walls where $\boldsymbol{n}$ is the unit normal outward to the wall. The fluid flux, $q e=($ $\phi^{f} \mathrm{u}^{f}$ ).n, across the capillary wall (of radius Ro) as shown in the final form (Eq. 6) accounts for a) the hydrostatic pressure difference across the capillary wall due to the hydraulic conductivity, $\tilde{L}_{p}$, b) a constant osmotic pressure gradient, $\sigma^{p}\left(\tilde{\pi}_{i}^{p}-\tilde{\pi}_{e}^{p}\right)$, due to protein molecules; and c) a variable osmotic pressure that depends on the concentration difference of the injected solute (of molecular weight $M_{w}^{s}$ and density $\rho_{T}^{s}$ ) in the intravascular (i) and the extravascular (e) space of a fibrous matrix with porosity $\varnothing$.

$$
\begin{array}{r}
q e=\tilde{L} p(P i|r=R o-P e| r=R o)-\sigma^{p}\left(\tilde{\pi}_{i}^{p}-\tilde{\pi}_{e}^{p}\right) \\
\left.-\left(\bar{P}+\frac{A}{\phi}\right) \frac{M_{w}^{s}}{\rho_{T}^{s}} \sigma^{s}\left(c_{i}^{s}\left|r=R o-c_{e}^{s}\right| r=R o\right)\right]
\end{array}
$$

Extravascular Space: The fluid transport in the extravascular space is influenced by a) the hydrostatic pressure difference in the tissue space, b) the hydraulic permeability of the tissue, $k$ and $\mathrm{c}$ ) the solute concentration gradients, $\nabla c^{s}$ in the tissue space as depicted in Eq. 7.

The retardation factor, $R_{F}^{s}$, is the ratio of the solute velocity and the inline fluid velocity in the tissue space. $\mathrm{A}$ is the interaction coefficient of the solute "s". A constant pressure Po is applied to the tissue boundary.

$$
-\nabla P-\frac{U f}{k}+\left(\bar{P}+\frac{A}{\phi}\right) \frac{M_{w}^{s}}{\rho_{T}^{s}}\left(1-R_{F}^{s}\right) \nabla c^{s}=0
$$

\section{Solute transport Equations}

Intravascular Space: The initial solute concentration, $C_{o}$, is used to prescribe the concentration at the inflow according to Eq. 8. The concentration time history for the five solutes prescribed at the blood vessel inlet is shown in Fig. 8. The concentration has been normalized by the peak intravascular concentration of each solute.

$$
\begin{aligned}
\text { cinlet }= & \left\{\begin{array}{c}
\frac{C o t}{15},(t<15 s) \\
0.5 \operatorname{Co}\left(e^{\frac{t 41}{60}}+e^{\frac{t 42}{60}}\right),(t>15 s)
\end{array}\right\} \\
A 1= & -7.23\left(M_{w}^{s}\right)^{0.38}, A 2=-0.062 \exp \left(-3.66 e^{-5} M_{w}^{s}\right) \\
& -0.0035 \exp \left(-5.78 e^{-7} M_{w}^{s}\right)
\end{aligned}
$$

Assuming a dilute solution of solute "s" (i.e. $\phi^{f} \approx 1$ ) and defining the solute concentration $c^{s}$ on a solvent volume basis as $c^{s}=\frac{\phi \phi^{s}}{M_{w}^{s}}$, the solute transport equation inside the microvessels where $D_{s f}$ is the solute diffusion coefficient is shown below:

$$
\frac{\partial c^{s}}{\partial t}+\mathrm{u}^{f} \cdot \nabla c^{s}+\nabla \cdot\left(-D s f \nabla c^{s}\right)=0
$$

Capillary wall: The solute particles have the same jump boundary conditions as the fluid at the capillary wall. The solute particles carried by the fluid flux and those which permeate into the tissue space due to the concentration difference across the capillary wall constitute the solute flux $\left(J_{s}\right)$ across it. Equation 10 is a modified version of Starling's law where $P_{d}^{s}$ is the solute permeability coefficient and $\sigma^{s}$ is the reflection coefficient.

$$
\begin{aligned}
J_{s}=\phi^{f} c^{s} u^{s} \cdot \mathrm{n}= & P_{d}^{s}\left(c_{i}^{s}\left|r=R o-c_{e}^{s}\right| r=R o\right) \\
& +\left(1-\sigma^{s}\right) \overline{c^{s}} q e
\end{aligned}
$$

Extravascular Space: In the porous matrix of the extravascular space the solute undergoes both advection and diffusion as shown in the governing transport Eq. 11.

$$
\phi \frac{\partial c^{s}}{\partial t}+R_{F}^{s} \mathrm{u}^{f} \cdot \nabla c^{s}+\nabla \cdot\left(-\phi D t i s s u e \nabla c^{s}\right)=0
$$

The mixture theory equations are appropriate for this study since it shows the dependence of tissue mechanical properties like hydraulic conductivity on chemical gradients that is not captured by traditional transport models [13].

\section{Difference of lymph vessel input parameters from that of blood vessel}

Solute concentration is zero at the lymph capillary inlet. The osmotic pressure gradient due to protein molecules is absent in the lymph vessel, $\left(\sigma^{p}\left(\tilde{\pi}_{i}^{p}-\tilde{\pi}_{e}^{p}\right)=0\right)$. The solute permeability coefficient, $P_{d}^{s}$, across the lymph capillary wall is twice its value in blood capillary wall shown in Table 1 to account for the free permeability of lymph vessels to macromolecules. The fluid flux and the solute flux equations are modified to allow intravasation only. 


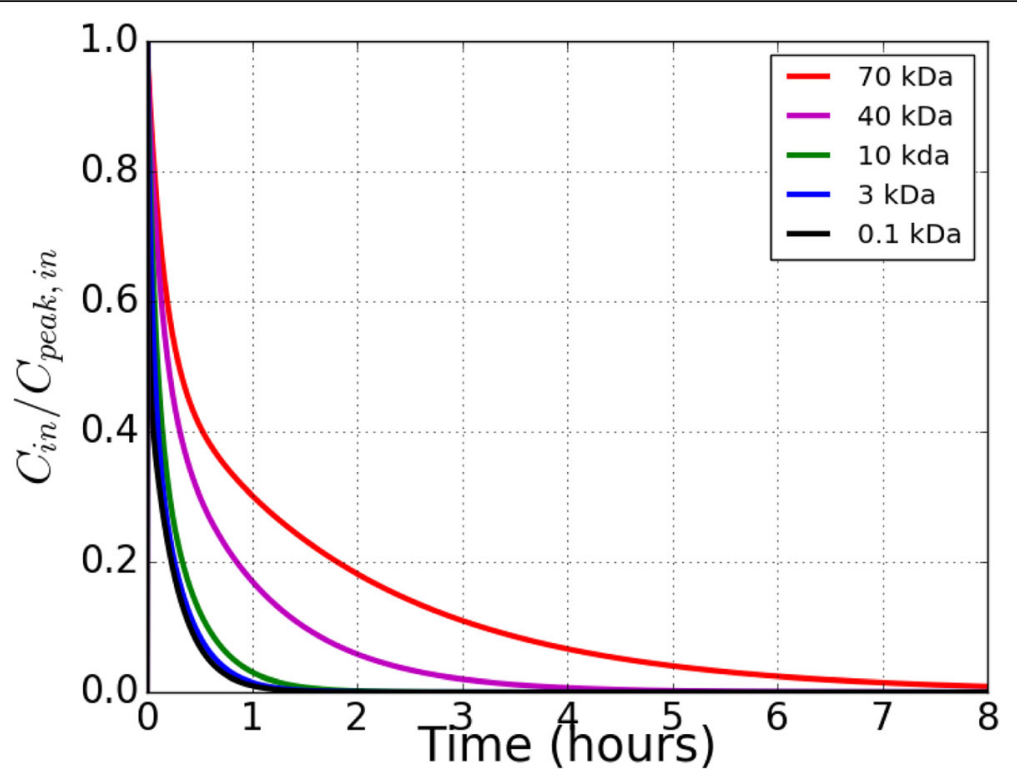

Fig. 8 Concentration vs Time profile of five solutes at the blood vessel inlet

\section{Appendix 2}

\section{Fabrication of microfluidic platform}

Type I collagen was used as the extracellular matrix of the tumor with a single integrated endothelialized blood vessel. Excised tendons from rat tails were dissolved in a $\mathrm{pH} 2.0 \mathrm{HCl}$ solution for $12 \mathrm{~h}$ at $23^{\circ} \mathrm{C}$. The solution was centrifuged at $30000 \mathrm{~g}$ for $45 \mathrm{~min}$ and sterilized using $10 \%(\mathrm{v} / \mathrm{v})$ chloroform for $24 \mathrm{~h}$ at $4{ }^{\circ} \mathrm{C}$. The mold for the in vitro tumor microfluidic platform with the embedded single vessel was fabricated as described in previous work [75, 76]. PDMS housing was fabricated using common soft-lithography methods. Polydimethylsiloxane (PDMS) and curing agent was mixed with 10:1 ratio and baked at $75^{\circ} \mathrm{C}$ for $1 \mathrm{~h}$. Hardened PDMS housing and the glass cover slip was plasma treated for $18 \mathrm{~W}$ for $30 \mathrm{~s}$. Plasma treated surfaces were assembled to create a permanent bonding. The housing was treated with $1 \%$ (v/v) polyethyleneimine in $\mathrm{dH}_{2} \mathrm{O}$ for 10 min followed by $0.1 \%(\mathrm{v} / \mathrm{v})$ glutaraldehyde in $\mathrm{dH}_{2} \mathrm{O}$ for $20 \mathrm{~min}$ and washed with $\mathrm{dH}_{2} \mathrm{O}$ twice. Collagen solution of $7 \mathrm{mg} / \mathrm{ml}$ was prepared by neutralizing stock solution with $1 \mathrm{X}$ DMEM, 10X DMEM, $1 \mathrm{~N} \mathrm{NaOH}$, and mixing $1 \times 10^{6} / \mathrm{ml}$ MDA-MB-231 breast cancer cells uniformly in collagen which was then placed in the housing. A 22G $(711 \mu \mathrm{m})$ needle was inserted into the mold and after polymerization and the needle removal, a cylindrical vascular channel was created within the collagen. $2 \times 10^{6}$ TIME cells were injected into the vascular channel and exposed to flow preconditioning protocols for 3 days to form a confluent, aligned endothelialized vessel. As a result, in vitro platform shown in Fig. 9 was fabricated.

\section{Measuring mechanical properties from fabricated tissue platform}

Porosity Vasculature porosity was measured using confocal microscopy and imaging mKate labeled TIME cells. Scanning electron microscopy (Zeiss, Super40) was used
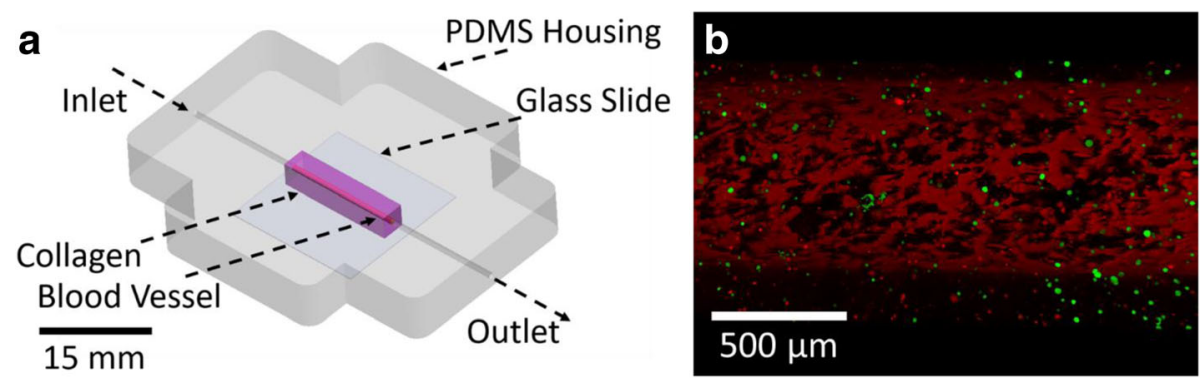

Fig. 9 3D vascularized in vitro microfluidic platform for experimental validation. a CAD drawing of the platform. b Confocal image of blood vessel with endothelial cells (red) surrounded by breast carcinoma cells (green) 
to image 3 fibrous matrix samples under $15 \mathrm{kx}, 20 \mathrm{kx}$, and $25 \mathrm{kx}$ magnifications at three vertical planes. Tissue porosity was measured by applying a Frangi filter on obtained images.

Solute Permeability Obtained intensity profiles of 3 $\mathrm{kDa}$ and $70 \mathrm{kDa}$ Dextran particles were used to calculate solute permeability coefficient as shown previously [77]. $3 \mathrm{kDa}$ and $70 \mathrm{kDa}$ dextran particles were suspended in serum free endothelial basal medium at $10 \mu \mathrm{g} / \mathrm{ml}$ concentration and perfused in the vascular channel at $260 \mu \mathrm{L} / \mathrm{min}$, which corresponds to $1 \mathrm{dyne} / \mathrm{cm}^{2}$ physiological shear stress for tumor vasculatures at every $3 \mathrm{~min}$ for $2 \mathrm{~h}$. The transport of these solutes was imaged using a confocal microscope (Leica SP8, 10X magnification). Normalized intensity profiles from this images as a function of time were used to compare with normalized concentration profiles from the equivalent numerical simulations.

Solute Diffusivity Fluorescence recovery after photobleaching (FRAP) technique was used as described previously by Voigt et al. to measure the diffusion coefficient for a range of dextran molecular weights $(4 \mathrm{kDa}-150 \mathrm{kDa})$ for varying $\mathrm{pH}$ values, collagen concentrations and temperatures $[78,79]$. We selected diffusivity values of 3 $\mathrm{kDa}$ and $70 \mathrm{kDa}$ for $\mathrm{pH} 7.6$, collagen concentration $7 \mathrm{mg} /$ $\mathrm{ml}$ at $37^{\circ} \mathrm{C}$ from the database of the mentioned study.

Hydraulic tissue permeability Hydraulic permeability for collagen at a concentration of $7 \mathrm{mg} / \mathrm{ml}$ as is used in fabrication of the platform were collected from the existing literature on vascularized in vitro experiments [42, 80, 81].

\begin{abstract}
Abbreviations
EPR: Enhanced Permeability and retention; SBC: Single Blood Capillary in tissue; 2 BC: 2 Blood Capillaries in tissue; BC_LC: Blood Capillary and Lymph Capillary in tissue; CO: Co-Current; CN: Counter-Current; L: Intercapillary separation length; l: length of capillaries; D : Tissue Diameter; $d$ : Capillary Diameter; $T^{*}$ : Non-dimensional time; $T^{*}$ peak: unique non-dimensional time for peak solute concentration in tissue; $\sigma_{s t d}$. standard deviation; $C^{*}$ : Non-dimensional concentration; $\mathrm{N}$ : number of samples in experiment; n: number of capillaries in tissue; Mw: Molecular Weight; kDa: KiloDalton; $\sigma$ : Reflection Coefficient; $P_{d}$ : Solute permeability Coefficient; $D_{f}$. Diffusion coefficient in fluid; $R_{F}$ : Retardation Factor; $\rho$ : Density of fluid; $\mu$ : Viscosity of fluid; $d P$ : Pressure drop along the capillary; Ф: Tissue Porosity; Co: Initial solute concentration at capillary inlet; Js: Solute flux at capillary wall; $q_{e}$ : Fluid flux at capillary wall; $\tilde{L}_{p}$ : hydraulic conductivity of the tissue
\end{abstract}

\section{Acknowledgements}

We would like to thank Professor Eric Nauman for introducing us to the mixture theory model for solute and fluid transport in tissues.

\section{Funding}

We would like to acknowledge funding provided by the National Institutes of Health Grant 5R21EB019646.

\section{Availability of data and materials}

Please contact author for data requests.

\section{Authors' contributions}

SC did the numerical simulations and $\mathrm{AO}$ did the experimental validation. MN, PV and WW discussed and reviewed the results. All authors edited and read the final version of the manuscript.
Ethics approval and consent to participate

Not Applicable.

\section{Consent for publication}

Not Applicable.

\section{Competing interests}

We declare that we have no competing interests.

\section{Publisher's Note}

Springer Nature remains neutral with regard to jurisdictional claims in published maps and institutional affiliations.

\section{Author details}

${ }^{1}$ Department of Mechanical Engineering, Purdue University, West Lafayette, IN 47907, USA. Department of Mechanical Engineering, The University of Texas at Austin, Austin, TX 78712, USA. ${ }^{3}$ Department of Biomedical Engineering, The University of Texas at Austin, Austin, TX 78712, USA. ${ }^{4}$ The Institute for Computational Engineering and Sciences, The University of Texas at Austin, Austin, TX 78712, USA. ${ }^{5}$ Department of Radiation Oncology, MD Anderson Cancer Center, Houston, TX 77030, USA.

Received: 24 February 2019 Accepted: 15 May 2019

Published online: 29 May 2019

\section{References}

1. Mariotto AB, Yabroff KR, Shao Y, Feuer EJ, Brown ML. Projections of the cost of cancer care in the United States: 2010-2020. J Natl Cancer Inst. 2011; 103(2):117-28.

2. Nie S, Xing Y, Kim GJ, Simons JW. Nanotechnology applications in cancer. Annu Rev Biomed Eng. 2007:9:257-88.

3. Haley B, Frenkel E. Nanoparticles for drug delivery in cancer treatment. Urol Oncol. 2008;26(1):57-64.

4. Arruebo M, Fernández-Pacheco R, Ibarra MR, Santamaría J. Magnetic nanoparticles for drug delivery. Nano Today. 2007:2(3):22-32.

5. Wang AZ, Langer R, Farokhzad OC. Nanoparticle delivery of cancer drugs. Annu Rev Med. 2012:63:185-98.

6. Matsumura Y, Maeda H. A new concept for macromolecular therapeutics in cancer chemotherapy: mechanism of tumoritropic accumulation of proteins and the antitumor agent smancs. Cancer Res. 1986;46(12 Pt 1):6387-92.

7. Zervantonakis IK, Chung S, Sudo R, Zhang M, Charest JL, Kamm RD. Concentration gradients in microfluidic 3D matrix cell culture systems. Int J Micro-Nano Scale Transport. 2010;1(1):27-36

8. Shipley RJ, Chapman SJ. Multiscale modelling of fluid and drug transport in vascular tumours. Bull Math Biol. 2010;72(6):1464-91.

9. Baxter LT, Jain RK. Transport of fluid and macromolecules in tumors. I. Role of interstitial pressure and convection. Microvasc Res. 1989;37(1):77-104.

10. Pozrikidis C, Farrow DA. A model of fluid flow in solid tumors. Ann Biomed Eng. 2003;31(2):181-94.

11. Sefidgar M, Soltani M, Raahemifar K, Sadeghi M, Bazmara H, Bazargan M, et al. Numerical modeling of drug delivery in a dynamic solid tumor microvasculature. Microvasc Res. 2015;99:43-56.

12. Penta R, Ambrosi D, Quarteroni A. Multiscale homogenization for fluid and drug transport in vascularized malignant tissues. Math Models Methods Appl Sci. 2015;25(01):79-108.

13. Schuff MM, Gore JP. Nauman EA. a mixture theory model of fluid and solute transport in the microvasculature of normal and malignant tissues. I. Theory. J Math Biol. 2013;66(6):1179-207.

14. Schuff MM, Gore JP, Nauman EA. A mixture theory model of fluid and solute transport in the microvasculature of normal and malignant tissues. II: factor sensitivity analysis, calibration, and validation. J Math Biol. 2013;67(6-7):1307-37.

15. Taylor DG, Bert JL, Bowen BD. A mathematical model of interstitial transport. II. Microvascular exchange in mesentery. Microvasc Res. 1990:39(3):279-306.

16. Taylor DG, Bert JL, Bowen BD. A mathematical model of interstitial transport. 1. Theory Microvasc Res. 1990:39(3):253-78.

17. Victorino GP, Newton CR, Curran B. Effect of hypertonic saline on microvascular permeability in the activated endothelium. J Surg Res. 2003; 112(1):79-83. 
18. Chou CY, Chang Wl, Horng TL, Lin WL. Numerical modeling of nanodrug distribution in tumors with heterogeneous vasculature. PLoS One. 2017; 12(12):e0189802.

19. Stylianopoulos T, Economides EA, Baish JW, Fukumura D, Jain RK. Towards optimal Design of Cancer Nanomedicines: multi-stage nanoparticles for the treatment of solid tumors. Ann Biomed Eng. 2015;43(9):2291-300.

20. Goins AB, Sanabria H, Waxham MN. Macromolecular crowding and size effects on probe microviscosity. Biophys J. 2008;95(11):5362-73.

21. Armstrong JK, Wenby RB, Meiselman HJ, Fisher TC. The hydrodynamic radii of macromolecules and their effect on red blood cell aggregation. Biophys J. 2004;87(6):4259-70.

22. Ekani-Nkodo A, Fygenson DK. Size exclusion and diffusion of fluoresceinated probes within collagen fibrils. Physical review E, statistical, nonlinear, and soft matter. physics. 2003;67(2 Pt 1):021909.

23. Ballard K, Perl W. Osmotic reflection coefficients of canine subcutaneous adipose tissue endothelium. Microvasc Res. 1978;16(2):224-36.

24. Michel CC. Filtration coefficients and osmotic reflexion coefficients of the walls of single frog mesenteric capillaries. J Physiol. 1980;309:341-55.

25. Yuan F, Salehi HA, Boucher Y, Vasthare US, Tuma RF, Jain RK. Vascular permeability and microcirculation of gliomas and mammary carcinomas transplanted in rat and mouse cranial windows. Cancer Res. 1994;54(17):4564-8.

26. Baxter LT, Jain RK. Vascular permeability and interstitial diffusion in superfused tissues: a two-dimensional model. Microvasc Res. 1988;36(1):108-15.

27. Baxter LT, Jain RK, Svensjo E. Vascular permeability and interstitial diffusion of macromolecules in the hamster cheek pouch: effects of vasoactive drugs. Microvasc Res. 1987;34(3):336-48.

28. Dreher MR, Liu W, Michelich CR, Dewhirst MW, Yuan F, Chilkoti A. Tumor vascular permeability, accumulation, and penetration of macromolecular drug carriers. J Natl Cancer Inst. 2006;98(5):335-44.

29. Nugent LJ, Jain RK. Extravascular diffusion in normal and neoplastic tissues. Cancer Res. 1984;44(1):238-44.

30. Maroudas A. Distribution and diffusion of solutes in articular cartilage. Biophys J. 1970;10(5):365-79.

31. Fox JR, Wayland $H$. Interstitial diffusion of macromolecules in the rat mesentery. Microvasc Res. 1979;18(2):255-76.

32. Leddy HA, Guilak F. Site-specific molecular diffusion in articular cartilage measured using fluorescence recovery after photobleaching. Ann Biomed Eng. 2003;31(7):753-60

33. Nakamura $\mathrm{Y}$, Wayland $\mathrm{H}$. Macromolecular transport in the cat mesentery. Microvasc Res. 1975;9(1):1-21.

34. Heldin $\mathrm{CH}$, Rubin K, Pietras K, Ostman A. High interstitial fluid pressure - an obstacle in cancer therapy. Nat Rev Cancer. 2004;4(10):806-13.

35. Lipowsky HH, Zweifach BW. Methods for the simultaneous measurement of pressure differentials and flow in single unbranched vessels of the microcirculation for rheological studies. Microvasc Res. 1977;14(3):345-61.

36. Zweifach BW, Lipowsky HH. Quantitative studies of microcirculatory structure and function. III. Microvascular hemodynamics of cat mesentery and rabbit omentum. Circ Res. 1977;41(3):380-90.

37. Asaishi K, Endrich B, Gotz A, Messmer K. Quantitative analysis of microvascular structure and function in the amelanotic melanoma A-Mel-3. Cancer Res. 1981;41(5):1898-904.

38. Stohrer M, Boucher $Y$, Stangassinger $M$, Jain RK. Oncotic pressure in solid tumors is elevated. Cancer Res. 2000;60(15):4251-5.

39. Jain RK. Transport of molecules in the tumor interstitium: a review. Cancer Res. 1987:47(12):3039-51.

40. Boucher Y, Kirkwood JM, Opacic D, Desantis M, Jain RK. Interstitial hypertension in superficial metastatic melanomas in humans. Cancer Res. 1991;51(24):6691-4.

41. Nathanson SD, Nelson L. Interstitial fluid pressure in breast cancer, benign breast conditions, and breast parenchyma. Ann Surg Oncol. 1994;1(4):333-8.

42. Serpooshan $\mathrm{V}$, Julien M, Nguyen $\mathrm{O}$, Wang $\mathrm{H}$, Li A, Muja N, et al. Reduced hydraulic permeability of three-dimensional collagen scaffolds attenuates gel contraction and promotes the growth and differentiation of mesenchymal stem cells. Acta Biomater. 2010;6(10):3978-87.

43. O'Connor SW, Bale WF. Accessibility of circulating immunoglobulin $\mathrm{G}$ to the extravascular compartment of solid rat tumors. Cancer Res. 1984;44(9):3719-23.

44. Gullino PM, Grantham FH, Smith SH. The interstitial water space of tumors. Cancer Res. 1965;25:727-31.

45. Appelgren L, Peterson HI, Rosengren B. Vascular and extravascular spaces in two transplantable tumors of the rat. Bibl Anat. 1973;12:504-10.
46. Less JR, Skalak TC, Sevick EM, Jain RK. Microvascular architecture in a mammary carcinoma: branching patterns and vessel dimensions. Cancer Res. 1991;51(1):265-73.

47. Smaje L, Zweifach BW, Intaglietta M. Micropressures and capillary filtration coefficients in single vessels of the cremaster muscle of the rat. Microvasc Res. 1970;2(1):96-110.

48. Edel MJ, Robbins PD, Papadimitriou JM, D'Antuono MF, Harvey JM, Mitchel CA, et al. Assessment of vascularity in breast carcinoma by computerassisted video analysis (CAVA) and its association with axillary lymph node status. Breast Cancer Res Treat. 1998;47(1):17-27.

49. Hilmas DE, Gillette EL. Morphometric analyses of the microvasculature of tumors during growth and after x-irradiation. Cancer. 1974;33(1):103-10.

50. Gerlowski LE, Jain RK. Microvascular permeability of normal and neoplastic tissues. Microvasc Res. 1986;31(3):288-305

51. Horak ER, Leek R, Klenk N, LeJeune S, Smith K, Stuart N, et al. Angiogenesis, assessed by platelet/endothelial cell adhesion molecule antibodies, as indicator of node metastases and survival in breast cancer. Lancet. 1992 340(8828):1120-4.

52. Yahara T, Koga T, Yoshida S, Nakagawa S, Deguchi H, Shirouzu K Relationship between microvessel density and thermographic hot areas in breast cancer. Surg Today. 2003:33(4):243-8.

53. Wells WA, Daghlian CP, Tosteson TD, Grove MR, Poplack SP, Knowlton-Soho S, et al. Analysis of the microvasculature and tissue type ratios in normal vs. benign and malignant breast tissue. Anal Quant Cytol Histol. 2004;26(3):166-74.

54. Fait E, Malkusch W, Gnoth S, Dimitropoulou C, Gaumann A, Kirkpatrick $C$, et al. Microvascular patterns of the human large intestine: morphometric studies of vascular parameters in corrosion casts. Scanning Microsc. 1998;12(4):641-51.

55. Konerding MA, Fait E, Gaumann A. 3D microvascular architecture of precancerous lesions and invasive carcinomas of the colon. Br J Cancer. 2001; 84(10):1354-62.

56. Lu Y, Michel CC, Wang W. Inert gas clearance from tissue by co-currently and counter-currently arranged microvessels. J Appl Physiol. 2012;113(3):487-97.

57. Malam Y, Loizidou M, Seifalian AM. Liposomes and nanoparticles: nanosized vehicles for drug delivery in cancer. Trends Pharmacol Sci. 2009;30(11):592-9.

58. Yang $\mathrm{H}-\mathrm{C}$, Hon $\mathrm{M}-\mathrm{H}$. The effect of the molecular weight of chitosan nanoparticles and its application on drug delivery. Microchem J. 2009;92(1):87-91.

59. NG AO, Hoopes PJ, Rylander MN. In Vitro vascularized liver and tumor tissue microenvironments on a Chip for dynamic determination of nanoparticle transport and toxicity. Biotechnol Bioeng. 2018;116(5):1201-19.

60. Michna R, Gadde M, Ozkan A, DeWitt M, Rylander M. Vascularized microfluidic platforms to mimic the tumor microenvironment. Biotechnol Bioeng. 2018;115(11):2793-806

61. Baxter LT, Jain RK. Transport of fluid and macromolecules in tumors. II. Role of heterogeneous perfusion and lymphatics. Microvasc Res. 1990:40(2):246-63.

62. Ji RC. Lymphatic endothelial cells, tumor lymphangiogenesis and metastasis: new insights into intratumoral and peritumoral lymphatics. Cancer Metastasis Rev. 2006;25(4):677-94.

63. Pisano M, Triacca $V$, Barbee KA, Swartz MA. An in vitro model of the tumorlymphatic microenvironment with simultaneous transendothelial and luminal flows reveals mechanisms of flow enhanced invasion. Integr Biol. 2015;7(5):525-33.

64. Swartz MA, Lund AW. Lymphatic and interstitial flow in the tumour microenvironment: linking mechanobiology with immunity. Nat Rev Cancer. 2012;12(3):210-9.

65. Shayan R, Achen MG, Stacker SA. Lymphatic vessels in cancer metastasis: bridging the gaps. Carcinogenesis. 2006;27(9):1729-38.

66. Alimohamadi $\mathrm{H}$, Imani M, Shojaeizadeh M. Numerical simulation of porosity effect on blood flow pattern and atherosclerotic plaques temperature; 2014

67. Cheema TA, Kim GM, Lee CY, Hong JG, Kwak MK, Park CW. Characteristics of blood vessel wall deformation with porous wall conditions in an aortic arch. Appl Rheol. 2014;24(24590):1-8.

68. McGeown JG. Passing on the legacy: teaching capillary filtration and developing presentation skills using classic papers. Adv Physiol Educ. 2006;30(3):108-12.

69. Chen J-S, Liu C-W. Generalized analytical solution for advection-dispersion equation in finite spatial domain with arbitrary time-dependent inlet boundary condition. Hydrol Earth Syst Sci. 2011;15(8):2471.

70. Van Genuchten MT. Analytical solutions of the one-dimensional convectivedispersive solute transport equation (No. 1661). US Department of Agriculture, Agricultural Research Service; 1982. 
71. Chapman SJ, Shipley RJ, Jawad R. Multiscale modeling of fluid transport in tumors. Bull Math Biol. 2008;70(8):2334-57.

72. Cheng MJ, Prabakaran P, Kumar R, Sridhar S, Ebong EE. Synthesis of functionalized 10-nm polymer-coated gold particles for endothelium targeting and drug delivery. JoVE (Journal of Visualized Experiments). 2018; (131):e56760.

73. Lu J, Yang S, Ng KM, Su C-H, Yeh C-S, Wu Y-N, et al. Solid-state synthesis of monocrystalline iron oxide nanoparticle based ferrofluid suitable for magnetic resonance imaging contrast application. Nanotechnology. 2006;17(23):5812.

74. Wu W, Wu Z, Yu T, Jiang C, Kim WS. Recent progress on magnetic iron oxide nanoparticles: synthesis, surface functional strategies and biomedical applications. Sci Technol Adv Mater. 2015;16(2):023501.

75. Antoine E, Buchanan C, Fezzaa K, Lee WK, Rylander MN, Vlachos P. Flow measurements in a blood-perfused collagen vessel using $x$-ray microparticle image velocimetry. PLoS One. 2013;8(11):e81198.

76. Buchanan CF, Voigt EE, Szot CS, Freeman JW, Vlachos PP, Rylander MN. Three-dimensional microfluidic collagen hydrogels for investigating flowmediated tumor-endothelial signaling and vascular organization. Tissue Eng Part C Methods. 2014;20(1):64-75.

77. Buchanan CF, Verbridge SS, Vlachos PP, Rylander MN. Flow shear stress regulates endothelial barrier function and expression of angiogenic factors in a 3D microfluidic tumor vascular model. Cell Adhes Migr. 2014;8(5):517-24.

78. Antoine EE, Vlachos PP, Rylander MN. Tunable collagen I hydrogels for engineered physiological tissue micro-environments. PLoS One. 2015; 10(3):e0122500.

79. Antoine EE. Mechanics and transport characterization of bioengineered tissue microenvironment platforms (Doctoral dissertation, Virginia Tech). 2014.

80. Cross VL, Zheng Y, Won Choi N, Verbridge SS, Sutermaster BA, Bonassar LJ et al. Dense type I collagen matrices that support cellular remodeling and microfabrication for studies of tumor angiogenesis and vasculogenesis in vitro. Biomaterials. 2010;31(33):8596-607.

81. Moreno-Arotzena O, Meier JG, Del Amo C, Garcia-Aznar JM. Characterization of fibrin and collagen gels for engineering wound healing models. Materials. 2015;8(4):1636-51.

Ready to submit your research? Choose BMC and benefit from:

- fast, convenient online submission

- thorough peer review by experienced researchers in your field

- rapid publication on acceptance

- support for research data, including large and complex data types

- gold Open Access which fosters wider collaboration and increased citations

- maximum visibility for your research: over $100 \mathrm{M}$ website views per year

At $\mathrm{BMC}$, research is always in progress.

Learn more biomedcentral.com/submissions 